\title{
Knowledge at Work: Some Neoliberal Anachronisms
}

\author{
Geoffrey M. Hodgson
}

1 February 2005

Published in the Review of Social Economy, December 2005
The Business School, University of Hertfordshire, De Havilland Campus, Hatfield, Hertfordshire AL10 9AB, UK http://www.herts.ac.uk/business http://www.geoffrey-hodgson.ws
Address for correspondence:
Malting House, 1 Burton End, West Wickham, Cambridgeshire CB1 6SD, UK
g.m.hodgson@herts.ac.uk

\section{KEY WORDS:}

Neoliberalism, firms, markets, employment contracts, knowledge, Veblen, Hobson

JEL classification: B15, B25, B52, B53, D20, D52, D82

\begin{abstract}
With a predilection for market solutions, neoliberalism upholds that the individual is generally the best judge of his or her interests. Yet markets are never universally applied as a mechanism of allocation and there are reasons, in principle, why capitalism will always have 'missing markets'. Concentrating on the application and appropriateness of neoliberal theory to the workplace, this essay argues that firms are not markets, despite some tendencies in modern theory to conflate the two. The employment contract is a key characteristic of modern firms, but neoliberal theory is often silent on the distinction between an employment contract and a contract for services, and largely ignores the asymmetrical rights of authority within contracts of employment. Furthermore, the social nature of knowledge represents a challenge to neoliberal theory and policy, because it sometimes makes it more difficult to define individual property rights. Accordingly, with the growth of the knowledge economy, neoliberalism to some extent is an anachronism.
\end{abstract}




\title{
Knowledge at Work: Some Neoliberal Anachronisms
}

\author{
Geoffrey M. Hodgson
}

\section{Introduction}

Neoliberalism upholds that the individual is generally the best judge of his or her interests, and that economic ends are generally best pursued through a market system involving private ownership and contractual exchange. It revives aspects of the classical liberalism of Adam Smith and others of two centuries ago. Neoliberalism is far from being a homogeneous doctrine and it has many variants, but it is generally defined in terms of the aforementioned propositions. ${ }^{1}$

In the second half of the twentieth century, the two most important proponents of this market individualist vision were Milton Friedman and Friedrich Hayek. These authors argued that a market system based on individual property rights and contracting provided the best guarantee of individual liberty. Such a system, as Hayek (1948, p. 18) put it, requires clear 'rules which, above all, enable man to distinguish between mine and thine.' These rights and rules provide the basis for a mutually advantageous system of contract, where as Friedman (1962, p. 13) argued, both parties to a transaction 'benefit from it, provided the transaction is bilaterally voluntary and informed.' Under such conditions, markets are alleged to provide the best available means of maximizing both individual liberty and economic welfare. ${ }^{2}$

Neoliberals differ among themselves on several theoretical issues, including on the validity or scope of an argument for government intervention based on the supposed existence of public goods, social costs or externalities. While some neoliberals accept a public-goods argument for some limited government activity, such as national defence, there has been a strong counter-trend to minimise the role of such arguments, even to the point of denial of the validity of some of these concepts (Coase, 1960, 1974; Dahlman, 1979).

I shall mention only in passing that a thoroughgoing market individualism would be incompatible with prominent conservative, authoritarian and anti-libertarian values such as the prohibition of drugs, restrictions on the trading of sex, capital punishment, a preference for the incarceration rather than rehabilitation of criminals, and patriarchal family values. In practice, individual rights are diminished in the case of children, criminals, and the insane.

\footnotetext{
1 This paper was first presented at a plenary session of the Association for Social Economics in Philadelphia on 6 January 2005. It makes use of some material from Hodgson (1999). The author is very grateful to the audience and two anonymous referees for comments.

2 However, in some important respects these authors differed, in analytic and policy terms. For example, Friedman alone proposed redistributive measures such as a negative income tax, and Hayek alone advocated the 'denationalization of money'. Of the two, Hayek did more to develop his philosophical and legal principles, many of which were refined during his debates against proponents of socialism or collective planning in the 1930s and 1940s.
} 
Furthermore, militarism and armed invasion can only be justified within such a philosophy by treating it as an exceptional and peculiar case, where the authoritarian means of war is somehow warranted by then end of establishing or restoring a market individualist regime, despite the fact that the population will resist or be deprived of the means of expressing their individual views on the matter, and even though military force is a lethal, coercive, authoritarian, and state-run enterprise. Notwithstanding these contradictions, the political triumph of market individualism in several countries since the 1970s, including in Britain and the United States, has entailed a coalition with prominent conservative and authoritarian values. But the focus here is on the rationale of modern neoliberalism, not its implementation in practice.

I shall also decline to elaborate the well-established but insufficiently acknowledged fact that the classical liberalism of earlier thinkers, including Smith and John Stuart Mill, was much more qualified in its individualism and advocacy of markets than many neoliberal propagandists acknowledge. Smith, for example, proposed a significant regulatory role for the state (Pack, 1991), whereas Mill advocated worker cooperatives and argued that individual satisfaction was not the universal metric of human welfare.

Although I wish to deal mainly with matters of analysis rather than policy, I first make some aspects of my political standpoint clear. Contrary to much traditional socialist thought, I think it neither possible nor desirable to marginalize markets within a modern complex economy. No feasible, developed and complex economic system has been proposed in which markets play less than a major role. On the other hand, markets differ hugely in their internal mechanisms and ramifications. In different cultural settings - compare the United States with Japan - market negotiations and mechanisms differ substantially. The outcomes of markets depend very much on the cultural and institutional contexts in which they operate, so we should avoid giving 'the market' universally either an unqualified positive or an unqualified negative moral sign. Nevertheless, markets are essential in wide sectors of industry and finance, particularly to accommodate and deal with innovation and change. No viable and dynamic alternative has ever been proposed.

On the other hand, there remain many important areas of economic activity, including within the family unit, where markets are unviable or undesirable. While some markets are essential in a modern complex society, no system makes them a universal form of allocation. As yet, no developed country has legally tolerated child prostitution or the selling of votes, for example. Absolute individual liberty and freedom of trade must admit the possibility of prostitution, of the selling of babies, and even of voluntary enslavement. Assaulting our 'individual liberty' and 'freedom of contract', the central legislatures of most countries typically place bounds or prohibitions upon such activities.

Indeed, there are logical limits to the extent of markets in a capitalist society, because in such a system there can be no futures markets for labour or skills. The existence of such markets would tie the worker to an employer in a future period. Such bonding or indenture is generally made illegal because if extended it would turn into a form of voluntary slavery. The absence of futures markets for labour is an important safeguard of the freedom of the employee.

However, the result of this 'missing market' is that the system may under-invest in human learning and education. As Alfred Marshall (1949, p. 470) wrote in his Principles (first published in 1890): 'we meet the difficulty that whoever may incur the expense of investing capital in developing the abilities of the workman, these abilities will be the property of the workman himself: and thus the virtue of those who have aided him must remain for the 
greater part its own reward.' If skills are to be adequate, then their development under capitalism must unrealistically depend, as Marshall put it, 'in great measure on the unselfishness of the employer.' If markets are a cure for this problem, as the market individualist might suggest, then these futures markets for labour can only be established at the cost of human liberty. As far as I am aware, the neoliberal literature is silent on this dilemma.

The argument in this paper centres on two important features of modern economies namely firms and employment contracts - and shows how these defining structures of capitalism sit uneasily with neoliberal principles of individual property and free trade. Unknowledge and uncertainty are essential to explain the existence of these structures. ${ }^{3}$ At the same time, unknowledge and uncertainty undermine the neoliberal conditions of free and fair contract. Neoliberals are forced either to denounce firms and employment contracts or to dilute the principles of individual property and free trade that are central to their philosophy. If they choose the former rather than the latter option then they are forced into the position of dismantling modern corporate structures and replacing it by a system of self-employed producers, without corporate firms. Arguably, such a highly fragmented system would be highly unsuited for the complex technological and productive realities of today.

Section two below is devoted to the firm, and upholds that it is not itself penetrated by market relations, although its products are often sold on markets. This absence of market relations within the core institution of capitalist enterprise is the first neoliberal anachronism. The third section emphasises the distinction between an employment contract and a contract for services. The existence of the employment contract depends on the existence of unknowledge and uncertainty concerning the process of work, which again challenges the informational preconditions that neoliberalism attributes to a free and fair contract. The fourth section discusses the social nature of knowledge and argues that it is difficult to decompose knowledge into discrete units that are possessed by individuals. This creates further problems for the accommodation of the employment contract within the neoliberal scheme. The fifth section concludes this essay.

\section{The Firm is Not a Market}

The corporation is a zone within which markets - in any adequate sense of that term - are absent: allocation and coordination are carried out by administrative rather than by market transactions (Simon, 1991). Accordingly, given the size and weight of the corporation in modern capitalism, the survival and pre-eminence of neoliberalism is somewhat surprising.

But many contemporary economists do not accept that the corporation is necessarily a market-free zone. They claim to identify 'internal markets' within firms. However, they make its essence and boundaries of the firm so vague that the identification of a frontier between the firm and the market is made impossible. In much of the literature there is a lack of a minimally adequate definition through which the firm itself can be identified. Instead we have the obfuscatory language of 'firm-market hybrids', 'hybrid forms', and 'quasi-firms' (Hodgson, 2002).

\footnotetext{
3 Unknowledge refers to absent knowledge of key attributes, techniques, events or circumstances. Uncertainty is distinguished from risk in the manner of Knight (1921), where uncertainty refers to outcomes for which no probability can be calculated.
} 
Much of this confusion is removed once we realize that the firm is a historically specific entity that has arisen in a historically specific legal framework, and the firm cannot be adequately understood without accommodating its legal aspects. The law regards the firm as a 'legal person' meaning that the organization as a whole is taken as a singular possessive actor for the purposes of the law, with the capacity to make contracts, such as hiring workers, buying inputs, and selling goods and services. Its legal singularity means that it cannot simultaneously divide its organization into multiple legal units, capable of making legally binding contracts between themselves and within the boundaries of the firm.

An objection to this logic would be that prices, exchanges and contracts do indeed exist within firms. For example, many large firms have divisions that act as cost centres. There are often internal negotiations and transfers of resources between divisions of modern firms, using price indicators for internal accounting. These divisions may have their own accounts and profit targets. But are there 'internal markets' within firms? A key test is whether or not these divisions have separate legal status and are recognized as 'legal persons'. Internal transfers within the firm do not involve the exchange of legal property rights. The objects of 'exchange' remain the property of the firm. These 'exchanges' are not legally enforceable contracts of trade: they are internal transfers. If a division of the firm is delegated the power to enter into contracts with outside bodies, then the firm as a whole is legally the party to the contract. The division is merely exercising delegated powers; it acts 'in the name' of the corporation, and the corporation as a whole is legally responsible for its liabilities under the agreed contract. Because the firm is a singular legal entity, legal trading within a firm is limited at best to such factors as the renegotiation of employment contracts, and does not apply to inter-divisional transfers.

Of course, there are cases where multiple firms are controlled by the same group of directors, or owned by the same parent company. This leads to cases where multiple firms begin to look and act like a single firm. In particular, multinational enterprises will exist as separate legal bodies in different countries, all owned by the headquarters corporation. To cope with these complications we need several terms, not one: such as 'firm', 'conglomerate' and 'multinational conglomerate'. It is important not to confuse these, as they refer to different structures and have different economic consequences.

The importance of real property rights, real contract enforceability, and real power to determine prices, was emphasized by Hayek $(1944,1948)$ and others in their powerful critique of the central planning scheme of Oskar Lange and Frederick Taylor (1938). The Lange-Taylor scheme involved an attempt to replicate aspects of the market, rather than the establishment of the market proper, despite its popular title of 'market socialism'. In this scheme the local managers would not have the power to make contracts and set prices themselves. This contrasts greatly with the powers of traders within genuine markets.

While Hayek identified some of the vital aspects of a market system, including the discretionary ability to make contracts along with their potential benefits and liabilities, these very criteria establish that the firm is not itself a market. If it is further argued that the market is the only appropriate system to deal with allocation and innovation, then one is left wondering how the firm as an organization - and particularly the large modern corporation can be justified within the Hayekian scheme. Hayek and other Austrians rightly point to the role of the entrepreneur in a context of uncertainty, but gives relatively little consideration to the organizational instruments that entrepreneurs may use or create to bring their innovative dreams to life. The emphasis is on the entrepreneur and the market, neglecting the relationship between the entrepreneur and the organization. 
The persuasive argument that the large firm is not a fully centralized system of planning either (Langlois, 1995), makes no difference here. Neither were Soviet-style command economies fully centralized; much 'planning' simply consisted of doing again what had been done before (Nove, 1979). The key point is that the Hayekian argument establishes that the firm is not a market, but fails to explain why firms actually exist. In pushing the ideal of the market to the extreme, little justification is offered for the existence of the firm. As a whole, Hayekian economics has little to say about the nature and internal organization of the firm. ${ }^{4}$

The explanation of the existence of the firm is a complex and still controversial matter that cannot be discussed adequately here. If we accept the widespread view that transaction costs are at least part of the story (Coase, 1937; Williamson, 1975), then this explanation relies on problems of uncertainty and information in the formulation, monitoring and enforcement of contracts (Dahlman, 1979).

In any case, the very existence of the firm, as a non-market mode of economic activity and allocation, challenges the neoliberal tenet that the market is always best. If this neoliberal proposition were true, then we would have no grounds to support the existence of the modern corporation. Neoliberalism extols individualism and the market, and demands that the powers of state administration should be minimized, but it is strangely silent about key questions concerning the other bureaucratic monsters in our midst: the modern corporations, within which administration and bureaucratic authority replace individual contract and market exchange. The following section examines an aspect of such non-market authority within the typical modern corporation.

\section{The Employment Contract}

Not all firms involve employment contracts: partnerships or cooperatives (without employees) can be exceptions. Nevertheless, most workers in most modern firms are employees, paid a wage or a salary for work according to a contract of employment. An employment contract differs from other contracts in important respects. This, as shown below, creates difficulties for the neoliberal vision.

A key difference between an employment contract and a contract for services is that in the employment contract the detailed pattern of work is unspecified. Instead, the employment contract specifies the general area of work, and invests the employer with the authority to direct the employee to particular activities when required (Simon, 1951). The employer has the power of control over the pattern and manner of work, within certain boundaries determined by stipulation, law or custom. Employment contracts are asymmetrical, in that powers of discretionary authority and interference are invested in one party rather than the other. This extensive 'right of control or interference' by an employer distinguishes the employment relation from a contract for services. If we enter into a contract for services with an individual, then we have no power of detailed control over the manner and pattern of work. The individual, self-employed contractor has much more detailed control than the employee over her work. Making this distinction in practice between employment and a contract for

\footnotetext{
${ }^{4}$ However, I do not wish to deny the important contributions of some authors that, while strongly influenced by Hayek, also draw heavily from other intellectual traditions, such as Langlois (1992) and Loasby (1998). It is certainly possible to synthesise Hayek's ideas with other approaches and gain important insights about the existence and internal organization of the firm.
} 
services is sometimes difficult, with messy boundary cases tested in law. But it is no less real or important for that (Deakin and Morris, 1995; Kahn-Freund, 1983; Wedderburn, 1971, 1993).

The very existence of the employment contract is due to problems of knowledge. If the nature of the required work was known for sure in advance, then there would be need for neither an employment contract nor employer authority, and a straightforward contract for services would be adequate. The employment contract enables the employer to deal with unforeseen circumstances and call upon the workers to change their activities in ways that cannot be anticipated at the outset. 5

Neoliberalism is largely silent about this dilemma, because it assumes that well-specified individual contracts are generally the best allocative mechanism. Some neoliberals argue that there is no substantial difference between an employment contract and everyday contracts for services or goods (Alchian and Demsetz, 1972). Neoliberalism is typically silent about the nature of asymmetrical authority inside the firm (Ciepley, 2004). Yet the question remains: why aren't employment contract eroded away by the rising tide of market freedom, to be replaced by contracts for services between entrepreneurs and self-employed producers and consultants? In a free market society, what basis or legitimation remains for a contract in which rights of control and interference are placed in the hands of one party but not the other (Ellerman, 1992)?

Although the employment contract has its origins in the norms of feudal service and the law of 'master and servant' (Batt, 1929; Deakin, 2001) this explains neither its remarkable persistence nor its global growth, to the point where it has eroded and replaced much selfemployment among peasants and artisans throughout the developed and developing world. The answer to this conundrum is that the employment relationship is the most useful, salient and historically tested mechanism for dealing with problems of complexity and uncertainty in the production process: it offers some flexibility to deal with unforeseen contingencies and changing perceptions of evolving complex phenomena.

Production processes depend upon dispersed, uncodifiable and tacit knowledge. They are generally complex to the degree that precise analysis and prediction are often confounded. The complexity and inaccessibility of much of this knowledge means that no worker or manager can know fully what is going on. For these reasons, employment contracts are imperfectly and incompletely specified. The terms of the contract cannot in practice be spelt out in full detail because of the complexity of the work process, and the degree of unpredictability of key outcomes. These problems of complexity and uncertainty are found to some degree in other contracts, but with employment contracts they are particularly severe.

Emile Durkheim (1984, p. 158) proposed in 1893 that 'in a contract not everything is contractual': there are factors, not reducible to the intentions or agreements of individuals, which have regulatory and binding functions for the contract itself. These consist of rules and norms that are not necessarily codified in law. The parties to the agreement have no alternative but to rely on institutional rules and standard patterns of behaviour, which cannot for practical reasons be established or confirmed by detailed negotiation. Significantly, such problems exist to a relatively high degree within employment contracts. Because of the more

\footnotetext{
5 While Marx (1867, chs. 6-7) clearly recognised the asymmetric relations of authority in the firm, and this crucial difference between a sales contract and an employment contract, he has no adequate explanation of why employment contracts exist.
} 
extensive and intense social interactions involved, they rely even more on (explicit and inexplicit) social conventions and norms, and even more on the cultural cement of loyalty and trust (Fox, 1974). In this case the practical limits to contractual specification are especially severe, and uncodifiable intangibles such as duty and precedent must fill in the gaps.

Among others, Joseph Schumpeter (1942), Karl Polanyi (1944) have noted that relations of employment cannot be completely reduced to explicit contracts. Schumpeter, for example, stressed that capitalism depended upon norms of loyalty and trust inherited from the former feudal era. Employment contracts are thus only partially successful attempts to encapsulate a messy and complex situation in contractarian terms. The difficulties outlined by Schumpeter, Polanyi and others cast severe doubt on the possibility of a purified capitalism operating through individual self-interest and explicit contract alone. All contracts, and especially the employment relationship, depend on factors additional to informed mutual consent.

Neoliberalism relies on the notions of defined property rights and informed consent. Within the employment relationship, the standard contractarian model of symmetrical and informed consent is modified by the existence of asymmetrical authority. Furthermore, employment contracts owe their existence to problems of uncertainty and unknowledge; neoliberalism is generally challenged by ubiquitous problems limiting the commodification of information and knowledge.

Unlike other commodities, the contractual transfer of information has some curious features that challenge and possibly impair the standard contractarian framework. Some of these oddities were pointed out several years ago by Richard Nelson (1959, p. 306) and developed by Kenneth Arrow (1962) in a famous article. Implicitly, Arrow confined his discussion to explicit and transferable information, and excluded tacit knowledge. First, once acquired, codifiable information can often be easily reproduced in multiple copies by its buyer, and possibly be sold to others. This places the seller at a disadvantage. Accordingly, there may be licences, patents or other restrictions to prevent the buyer from selling it on to others. Second, information has the peculiar property that, once it is sold, it also remains in the hands of the seller. Information is not a 'normal' commodity that changes hands from seller to buyer when it is purchased. Thomas Jefferson allegedly likened knowledge to the light of a candle: even as its flame is passed on to another candle, its own light is not weakened. Third, and crucially for our purposes here, Arrow (1962, p. 616) wrote: 'there is a fundamental paradox in the determination of demand for information: its value for the purchaser is not known until he has the information, but then he has in effect acquired it without cost'. If we knew what we were going to buy then we would no longer need to buy it.

As a result, in an economy involving substantial flows of information, it is not always possible, to use Hayek's (1948, p. 18) possessive phraseology, to establish clear 'rules which, above all, enable man to distinguish between mine and thine'. As Arrow suggested, information challenges the bounds of exclusive and individual property. For instance, what is sold as information remains also the property of the seller. Outside the restrictions of patent laws, what is possessed cannot always be clearly defined, because to define it openly is to give it away. It is often unclear as to who owns what information. It is not always possibly to break up information into discrete pieces and give each one an ownership tag. It is often difficult to determine who 'discovered' the information in the first place, and who can thus claim legal title to its 'ownership'. Far from being transparent, in an information-rich society what is 'mine' and what is 'thine' may become increasingly mysterious.

In particular, the crucial problem of not knowing what we are buying until after we have bought it is clearly manifest in many modern employment contracts. This is especially the 
case with highly specialized and skilled employees, where the hirers do not share the same skill and thus cannot know what they have hired, and will thus be unable to make a fullyinformed judgment of employee competences. Even if the interviewing panel did have these skills, it would be extremely unlikely that the higher managers appointing the members of the panel would have them as well. Who judges the judgment of the judges? This information problem was explored by Frank Knight (1921) in his classic work on the firm. He identified the intractable problem of 'judgment of judgment' (p. 311) in a climate of unknowledge and uncertainty. How do we judge the capabilities of others to make good decisions, in regard to matters with which we are ourselves unfamiliar? In other words, the purchase or allocation of knowledge or competence itself requires knowledge or competence, and there is a potential problem of infinite regress (Pelikan, 1989). At the minimum, this undermines Freidman's (1962, p. 13) requirement of full information for a mutually beneficial transaction. At the maximum, the development of finite number of markets for skilled labour requires some skills of judgment that are not themselves hired on markets.

Typically it will be assumed that the potential employee will learn many of the particular skills after he or she is appointed. Such learning will often depend on imitation and close interaction with others at work. But it is impossible to specify fully in advance the skills that a worker may acquire while working on the job, or to detail the information that may be transferred and the learning experiences that may occur.

Difficulties of this kind do not arise simply at the selection and appointment of an employee. They remain during the subsequent period of employment. By definition, employment involves potential control and supervision by others. However, as Drucker (1993, p. 107) asserts, the modern 'organization is increasingly composed of specialists, each of whom knows more about his or her own speciality than anybody else in the organization.' This creates a supervisory problem. If the worker has the highly specific and idiosyncratic skills that are needed in a complex economy, then the extent of proficient supervision and control of the worker depends also on the possession of relevant capabilities by the supervisor. In an increasing number of cases, these capabilities will be lacking. Close and highly evaluative supervision, based on a hierarchy of command, will be less viable, simply because the nominal supervisors will not know the best way of doing the job - or even the precise purpose of the specialist job itself - and the worker will know better.

The shift from physical to intellectual work also compounds the problem. Even though managers lacked complete knowledge of the idiosyncratic skills required in action-centered work, at least they could observe the physical activity and its output, and make semi-informed judgments concerning the efficiency and aptitude of the worker. In contrast, with intellective skills, meaningful supervision is less viable. We can observe manual work, but it is impossible to see what is going on in someone's head (Zuboff, 1988).

Admittedly, developments in information technology would in some respects make sophisticated surveillance of the workforce possible. However, such surveillance would mainly concern the location and visible engagement of the workers, not the internal workings of the mind, nor the evaluation of the details of knowledge-intensive work. Just as managers cannot know much of what their workers know, neither can a video- or computer-based monitoring system.

To some degree, problems associated with a degree of complexity existed in early industrial capitalism, even when manual workers were operating looms, digging ditches or sharpening pins. Workers have always possessed some tacit and other skills beyond the reach 
of managerial comprehension. But in modern, complex, knowledge-intensive capitalism the predicament has become immensely more compounded and severe.

\section{Socially Embedded Knowledge}

The relative importance of the physical means of production in the production process, compared with knowledge and other 'intangible assets,' has typically been over-stressed by mainstream and non-mainstream economists alike. Mainstream economists have long depicted the contribution of physical 'capital', alongside 'labour', to production, treating them both as inputs into a mechanistic function. Heterodox economists from Karl Marx to Piero Sraffa have also stressed tangible rather than intangible assets. ${ }^{6}$

Against this overwhelming trend, Thorstein Veblen was one of the first to stress the relative importance of immaterial assets, including the 'knowledge and practice of ways and means' (Veblen, 1919, p. 343). For Veblen (1919, pp. 185-6) production relied on 'the accumulated, habitual knowledge of the ways and means involved ... the outcome of long experience and experimentation'. The production and use of all material and immaterial assets depends on elusive, immaterial circumstances and combinations of skills, which are often difficult to identify and own. These capacities depend on the institutions and culture of the socio-economic system, and are built up over a long period of time. Accordingly, 'the capitalist employer is ... not possessed of any appreciable fraction of the immaterial equipment' that is drawn upon every day in the process of production (Veblen, 1919, p. 344). ${ }^{7}$

In contrast, mainstream explanations of economic growth have stressed changes in factor inputs, on the one hand, and technological changes driven by research and development, on the other. Emphasis on such tangible inputs and measures has obscured the importance of the accumulation of knowledge. Again this trend, Kenneth Boulding (1966, p. 6) pointed out that economic development is essentially a knowledge process, 'but we are still too much obsessed by mechanical models, capital-income ratios, and even input-output tables, to the neglect of the study of the learning process which is the real key to development.'

There is still a tendency to treat knowledge and skills as discrete and separable substances, stored up and possessed by individuals, alongside and akin to their material wealth. For example, the widespread use of the term 'human capital' often misleads us by suggesting that accumulated knowledge and skills are substances which are readily measurable in monetary terms and generally tradable on the market. By contrast, knowledge is relational and contextual, in that its meaning depends upon interpretative frameworks and circumstances (Langlois, 2001; Nooteboom, 2000). A social or local culture provides interpretations and meanings, and all knowledge is dependent on this context. Social institutions are structures that preserve and reproduce these cultural conventions. We rely on these institutions, and interaction with others, to acquire the cognitive capacity to make sense of the chaotic

\footnotetext{
${ }^{6}$ Heterodox economists, especially Marx, have also emphasised the social character of productive activity. Marx had less to say, however, about the role of intangible assets and the nature of knowledge. It was Veblen who brought these things to the fore.

7 The concept of intangible assets was taken up and developed by John R. Commons (1924, pp. 235-82; 1934, pp. 649-72).
} 
multitude of data that reach our senses. We rely on the social institution of language in order to receive and communicate information (Hodgson, 1988).

Neoliberalism proposes that people have a stronger incentive to improve their condition when through ownership of property they reap the rewards of their efforts. They propose 'a regime that allows the acquisition of property' wherein the individual 'on his own account' may 'better his condition ... quite independently of any complementing collective action, beyond that required for the necessary functioning of the legal order' (Buchanan, 1993, p. 51). Here the role of 'collective action' is limited to establishing and sustaining the legal framework. This ignores the social dimension of knowledge, and the dependence of the individual on others to reach any understanding about the world. Our reliance on these additional social institutions increases with volume of information and degree of complexity in the socio-economic sphere.

For these reasons, knowledge is not completely divisible into separate units, and can never be fully commodified. Furthermore, all knowledge depends on the cultural and institutional context, which is of a social character and cannot become the object of property of any individual or group. As Veblen (1898, pp. 353-4) argued: 'The isolated individual is not a productive agent. ... There can be no production without technical knowledge; hence no accumulation and no wealth to be owned, in severalty or otherwise. And there is no technical knowledge apart from an industrial community.' Building on Veblen's argument, John A. Hobson (1936, p. 67) similarly argued that productivity could not be explained wholly in terms of the 'factors' owned by individual agents:

The productivity of workers on the soil or in the factory depends for its amount and quality not entirely and not chiefly upon their working energy, but upon economic conditions under which they work that lie outside their personal control. First and foremost among these conditions is the state of the industrial arts, a rich social inheritance of long accumulation, which is the basis of all skilled workmanship. No living worker or group of workers can properly lay claim to this accumulated knowledge as his private possession, though he is entitled to utilize it in order to increase his productivity.

Learning is an instituted process of interpretation, appraisal, trial, feedback, and evaluation, involving socially-transmitted cognitive frames and routinized group practices, which are often taken for granted. Learning is context dependent, culture-bound and institutionalized.

These arguments have crucial implications for the neoliberal conception of the employment contract. Social and organisational knowledge - the relational interconnection of knowledge throughout the system - make it difficult to establish, in terms of intellectual property, what is 'mine and thine' for much of the tacit and codifiable knowledge in the economy. Accordingly, the employment contract is not a straightforward exchange of a wage or salary for individual skills and capacities. These skills and capacities depend upon the social context, which is owned by no-one but is essential to all productive and technological activity.

Admittedly, part of this cultural and institutional context is specific to the firm in question, and thus is part of the intangible assets of that firm. Capabilities do not reside merely in individuals because they are partly dependent on the organizational context. The value of individual skills depends upon their employment in particular organizational settings. The work process entails a process of inquiry, reflection and evaluation in which the model that is 
shared by several people is adapted and embedded in the regular practices of the organization. ${ }^{8}$

However, the intangible knowledge assets of the firm are only a small part of the story. Similar considerations concerning the role of culture, interpretative frameworks and context also apply to the society as a whole. A skilled worker may be able to increase his or her productivity and remuneration by a few percentage points by moving from one firm to another in a given region. But when a skilled worker moves from (say) Bangladesh to (say) the United States, the increase in productivity and remuneration can be much greater. This cannot be adequately explained by the differences in corporate culture alone, because similarly large increases would often apply to a self-employed skilled worker. The most important factor is the difference in the broader and inherited 'state of the industrial arts', involving a much denser network of knowledge-rich interactions in the more developed country.

Because employment capabilities depend on social as well as organizational contexts, the employment contract is not in essence a straightforward 'exchange' of atomistic rights and contributions between the firm and the worker. Both also depend on the social culture and other social institutions, which are not in the possession of any identifiable agent. The social character of knowledge and skilled work thus undermines the neoliberal presumption that we can readily distinguish between 'mine' and 'thine'.

Furthermore, as noted above, monitoring and control is made much more difficult by the complex and interrelated character of production. In sum, the employment contract is in large measure a convenient fiction, couched in the individualistic categories of modern contract law, which in fact masks the social and co-operative character of all productive activity. Although the employment relationship has been profitably adapted to the modern world of complex and uncertain production, the increasing reliance on socially embedded knowledge puts a strain on a contractarian formulation based on individual assets.

Accordingly, neoliberal assumptions are generally ill-suited to the capitalist world of firms and employment contracts. Furthermore, insofar as capitalist development involves greater use of knowledge and skills, the distance of the modern world from the neoliberal ideal type of definable individual contracting of discrete individual property becomes even greater. The increasing complexity and knowledge intensity of the production process widens the mismatch between productive realities and individualistic formulations of the employment contract. As production becomes more interrelated and social in its character, neoliberalism becomes increasingly an anachronism (Hodgson, 1999).

\section{Conclusion}

The neoliberal precepts of market individualism arose in the seventeenth century and remain, if anything, more suited to that age of production dominated by small-craft and self-employed producers, than to the modern world of work controlled by corporations and contracts of employment. But neoliberal theory cannot explain the existence of employment relations even within Smith's pin factory, and has become increasingly anachronistic as more and more workers have been employed by capitalist firms.

\footnotetext{
8 See, for example, Argyris and Schön (1978, 1996), Winter (1982), Aoki (1990), Dosi and Marengo (1994), Teece and Pisano (1994).
} 
Neoliberalism has difficulty distinguishing between a firm and a market, explaining the absence of true markets within the firm, and further distinguishing between an employment contract and a contract for services. Once these important distinctions are upheld, the questions emerge of why firms and employment contracts exist. The answers lie in part in the degree of complexity, unknowledge and uncertainty surrounding modern production processes. These institutional arrangements have survived in part because of their capacity to deal with such an environment.

Veblen acknowledge the socially embedded nature of productive knowledge, and this idea is incorporated in much modern literature in business economics and organization science. It has profound consequences for the individualist, possessive and contractarian foundations of neoliberalism. Crucially, it is no longer possible to break all knowledge down into pieces and give each one an ownership tag. Yet knowledge is a central and increasingly paramount resource. This has implications for the proposal that productive resources should become tradable objects of possession, and particular implications for the employment contract and employee remuneration.

Most neoliberals acknowledge some legitimate and limited scope for government intervention. Hayek (1960) to his credit laid out some of the limits to market allocation and prescribed a limited constitutional role for the state. But adequate answers to the conceptual problems outlined here relating to firms and employment are absent from his works. In particular, the socially embedded nature of knowledge raises questions concerning an enlarged role of state in creating and fostering the knowledge base.

Such issues were posed eloquently in 1841 by Friedrich List (1904) in his critique of British classical economics, where he proposed a developmental role for the state, involving the promotion of a system of education and training. In their responses to nineteenth century market individualists such as Herbert Spencer (1884), Durkheim in 1893 and Hobson in 1902 identified the limits of individualistic and contractarian arrangements, and the dependence of a market economy on social institutions and norms that are not readily sustained through market trading alone (Durkheim, 1984; Hobson, 1902).

These earlier examples show that objections to market individualism are not confined to those socialists that would place the market in a marginal role and substitute a substantial apparatus for central planning. Indeed, sophisticated criticism of market individualism by more nuanced and moderate thinkers such as List, Durkheim and Hobson, has been overshadowed in the twentieth century by the great debate between more extreme formulations of socialism and capitalism. Ultimately, the viability and dynamic efficiency of schemes of comprehensive collective planning have been fatally challenged in theory and undermined by the Soviet Bloc experience. The collapse of the Soviet Bloc in 1989-91 signalled to many that neoliberalism had won that debate. However, the very growth of complexity and global traffic in information - which had placed intolerable burdens on the Soviet regime (Bergson, 1978; Haddad, 1995) - has also compromised the neoliberal analysis. To a large extent, neoliberalism was the Soviet alter-ego. It is no accident that the terms 'socialism' and 'individualism' both emerged in French and English in the 1820-40 period, in similar intellectual contexts (Bestor, 1948). For much of two centuries, the one doctrine has fed on the other.

Especially when placed in the context of a modern knowledge-intensive economy, the argument here points to a revival, not of the tired old dichotomy between widespread free markets and comprehensive planning, but to a middle-ground philosophy that involves substantial, limited and complementary roles for both markets and states. In this regard we 
can learn much from the substantial Anglo-American 'social democratic' or 'social liberal' streams of thought that include T. H. Green, D. G. Ritchie, J. A. Hobson, John Dewey, John Maynard Keynes, and John Kenneth Galbraith. Reality fits into neither a Marxian nor a neoliberal mould. 


\section{References}

Alchian, Armen A. and Demsetz, Harold (1972) 'Production, Information Costs, and Economic Organization', American Economic Review, 62(4), December, pp. 777-95.

Aoki, Masahiko (1990b) 'The Participatory Generation of Information Rents and the Theory of the Firm', in Aoki, Masahiko, Gustafsson, Bo and Williamson, Oliver E. (eds) (1990) The Firm as a Nexus of Treaties (London: Sage), pp. 26-51.

Argyris, Chris and Schön, Donald A. (1978) Organizational Learning: A Theory of Action Perspective (Reading, MA: Addison-Wesley).

Argyris, Chris and Schön, Donald A. (1996) Organizational Learning II: Theory, Method, and Practice (Reading, MA: Addison-Wesley).

Arrow, Kenneth J. (1962) 'Economic Welfare and the Allocation of Resources to Invention', in Nelson, Richard R. (ed.) The Rate and Direction of Inventive Activity: Economic and Social Factors (Princeton: Princeton University Press), pp. 609-25.

Batt, Francis R. (1929) The Law of Master and Servant (New York: Pitman Publishing).

Bergson, Abram (1978) 'The Soviet Economic Slowdown', Challenge, 20(6).

Bestor, Arthur E., Jr (1948) 'The Evolution of the Socialist Vocabulary', Journal of the History of Ideas, 9(3), June, pp. 259-302.

Boulding, Kenneth E. (1966) 'The Economics of Knowledge and the Knowledge of Economics', American Economic Review (Papers and Proceedings), 56(1), March, pp. 113.

Buchanan, James M. (1993) Property as a Guarantor of Liberty (Aldershot: Edward Elgar).

Ciepley, David (2004) 'Authority in the Firm (And the Attempt to Theorize it Away)', Critical Review, 16(1), pp. 81-115.

Coase, Ronald H. (1937) 'The Nature of the Firm', Economica, 4, November, pp. 386-405.

Coase, Ronald H. (1960) 'The Problem of Social Cost', Journal of Law and Economics, 3, October, pp. 1-44.

Coase, Ronald H. (1974) 'The Lighthouse in Economics', Journal of Law and Economics, 17, October, pp. 357-76.

Commons, John R. (1924) Legal Foundations of Capitalism (New York: Macmillan).

Commons, John R. (1934) Institutional Economics - Its Place in Political Economy (New York: Macmillan).

Dahlman, Carl J. (1979) 'The Problem of Externality', Journal of Law and Economics, 22(1), April, pp. 141-62.

Deakin, Simon (2001) 'The Contract of Employment: A Study in Legal Evolution', Historical Studies in Industrial Relations, 11, pp. 1-36.

Deakin, Simon and Morris, Gillian S. (1995) Labour Law (London: Butterworth).

Dosi, Giovanni and Marengo, Luigi (1994) 'Some Elements of an Evolutionary Theory of Organizational Competences', in England, Richard W. (ed.) (1994) Evolutionary Concepts in Contemporary Economics (Ann Arbor, MI: University of Michigan Press), pp. 157-78. 
Drucker, Peter F. (1993) Post-Capitalist Society (Oxford: Butterworth-Heinemann).

Durkheim, Émile (1984) The Division of Labour in Society, translated from the French edition of 1893 by W. D. Halls with an introduction by Lewis Coser (London: Macmillan).

Ellerman, David P. (1992) Property and Contract in Economics: The Case for Economic Democracy (Oxford: Basil Blackwell).

Friedman, Milton (1962) Capitalism and Freedom (Chicago: University of Chicago Press).

Fox, Alan (1974) Beyond Contract: Work, Power and Trust Relations (London: Faber and Faber).

Haddad, Louis (1995) 'The Disjunction Between Decision-Making and Information Flows: The Case of the Former Planned Economies' in Groenewegen, Peter and McFarlane, Bruce (eds) (1995) Socialist Thought in the Post Cold War Era (Manila, Philippines: Journal of Contemporary Asia Publishers), pp. 69-88.

Hayek, Friedrich A. (1944) The Road to Serfdom (London: George Routledge).

Hayek, Friedrich A. (1948) Individualism and Economic Order (London and Chicago: George Routledge and University of Chicago Press).

Hayek, Friedrich A. (1960) The Constitution of Liberty (London and Chicago: Routledge and Kegan Paul, and University of Chicago Press).

Hobson, John A. (1902) The Social Problem: Life and Work (London: James Nisbet).

Hobson, John A. (1936) Veblen (London: Chapman and Hall).

Hodgson, Geoffrey M. (1988) Economics and Institutions: A Manifesto for a Modern Institutional Economics (Cambridge and Philadelphia: Polity Press and University of Pennsylvania Press).

Hodgson, Geoffrey M. (1999) Economics and Utopia: Why the Learning Economy is not the End of History (London and New York: Routledge).

Hodgson, Geoffrey M. (2002) 'The Legal Nature of the Firm and the Myth of the FirmMarket Hybrid', International Journal of the Economics of Business, 9(1), February, pp. 37-60.

Kahn-Freund, Otto (1983) Labour and the Law, 3rd edn., ed. P. Davies and M. Freedland (London: Stevens).

Knight, Frank H. (1921) Risk, Uncertainty and Profit (New York: Houghton Mifflin).

Lange, Oskar R. and Taylor, Frederick M. (1938) On the Economic Theory of Socialism, ed. Benjamin E. Lippincot (Minneapolis: University of Minnesota Press).

Langlois, Richard N. (1992) 'Transaction Cost Economics in Real Time', Industrial and Corporate Change, 1(1), pp. 99-127.

Langlois, Richard N. (1995) 'Do Firms Plan?', Constitutional Political Economy, 6, pp. 24761.

Langlois, Richard N. (2001) 'Knowledge, Consumption, and Endogenous Growth', Journal of Evolutionary Economics, 11(1), pp. 77-93. 
List, Friedrich (1904) The National System of Political Economy, translated from the German edition of 1841 by Sampson S. Lloyd, with an introduction by J. Shield Nicholson (London: Longmans, Green).

Loasby, Brian J. (1998) 'The Organisation of Capabilities', Journal of Economic Behavior and Organization, 35(2), April, pp. 139-160.

Marshall, Alfred (1949) The Principles of Economics, 8th (reset) edn. (1st edn. 1890) (London: Macmillan).

Marx, Karl (1867) Das Kapital: Kritik der politischen Ökonomie, vol. 1 (Hamburg: Meissner).

Nelson, Richard R. (1959) 'The Simple Economics of Basic Scientific Research', Journal of Political Economy, 67(3), June, pp. 297-306.

Nooteboom, Bart (2000) Learning and Innovation in Organizations and Economies (Oxford and New York: Oxford University Press).

Nove, Alexander (1979) Political Economy and Soviet Socialism (London: George Allen and Unwin).

Pack, Spencer J. (1991) Capitalism as a Moral System: Adam Smith's Critique of the Free Market Economy (Aldershot: Edward Elgar).

Pelikan, Pavel (1989) 'Evolution, Economic Competence, and Corporate Control', Journal of Economic Behavior and Organization, 12, pp. 279-303.

Polanyi, Karl (1944) The Great Transformation: The Political and Economic Origins of Our Time (New York: Rinehart).

Schumpeter, Joseph A. (1942) Capitalism, Socialism and Democracy, 1st edn. (London: George Allen and Unwin).

Simon, Herbert A. (1951) 'A Formal Theory of the Employment Relationship', Econometrica, 19, July, pp. 293-305.

Simon, Herbert A. (1991) 'Organizations and Markets', Journal of Economic Perspectives, 5(2), Spring, pp. 25-44.

Spencer, Herbert (1884) The Man versus The State, 1st edn. (London: Williams and Norgate).

Teece, David J. and Pisano, Gary (1994) 'The Dynamic Capabilities of Firms: An Introduction', Industrial and Corporate Change, 3(3), pp. 537-56.

Veblen, Thorstein B. (1898) 'The Beginnings of Ownership', American Journal of Sociology, 4(3), November, pp. 352-65.

Veblen, Thorstein B. (1919) The Place of Science in Modern Civilization and Other Essays (New York: Huebsch).

Wedderburn, Kenneth W. (1971) The Worker and the Law, 2nd edn. (Harmondsworth: Penguin).

Wedderburn, Kenneth W. (1993) Labour Law and Freedom: Further Essays in Labour Law (London: Lawrence and Wishart).

Williamson, Oliver E. (1975) Markets and Hierarchies: Analysis and Anti-Trust Implications: A Study in the Economics of Internal Organization (New York: Free Press). 
Winter, Sidney G., Jr (1982) ‘An Essay on the Theory of Production', in Hymans, Saul H. (ed.) (1982) Economics and the World Around It (Ann Arbor, MI: University of Michigan Press), pp. 55-91.

Zuboff, Shoshana (1988) In the Age of the Smart Machine: The Future of Work and Power (Oxford: Heinemann). 